\title{
Friction stir welding of Aluminium matrix composites - A Review
}

\author{
Prabhu Subramanya ${ }^{1 *}$, Murthy Amar ${ }^{2}$, Shettigar Arun ${ }^{2}$, Herbert Mervin ${ }^{1}$ and Rao \\ Shrikantha ${ }^{1}$ \\ ${ }^{1}$ NITK Surathkal, Karnataka, India \\ ${ }^{2}$ Department of Mechanical and Manufacturing Engineering, Manipal Institute of Technology, \\ Manipal Academy of Higher Education, Manipal, Karnataka, India
}

\begin{abstract}
Friction stir welding (FSW) is established as one of the prominent welding techniques to join aluminium matrix composites (AMCs). It is a solid state welding process, takes place well below the melting temperature of the material, eliminates the detrimental effects of conventional fusion welding process. Although the process is capable to join AMCs, challenges are still open that need to be fulfill to widen its applications. This paper gives the outline of the friction stir welding technique used to join AMCs. Effect of process variables on the microstructure and mechanical properties of the joints, behavior of reinforcing materials during welding, effect of tool profiles on the joint strength are discussed in detail. Few improvements and direction for future research are also proposed.
\end{abstract}

\section{Introduction}

Aluminium Matrix composites reinforced with particulates are considered as an ideal material for aerospace automotive, marine application as it displays better mechanical properties compared to aluminium and its alloys. AMC possess high strength to weight ratio, higher formability and higher resistance to wear and corrosion [1, 2]. However, the potential application of AMCs are limited if a proper welding process is not developed [3, 4]. AMCs joined through conventional fusion welding methods unveils several short comes in terms of quality of joints. Fusion welding leads to the formation of harmful phases in the joint region due to excessive heat, cracking, porosity, distortion and settling of hard particles at the bottom of the weld region due to the difference in densities [5-7]. A solid state welding process seems a favorable joining method for AMCs.

Friction stir welding is a solid state welding process, was developed and patented by The Welding Institute (TWI) in 1991, to weld aluminium alloys [8]. It was then efficaciously tried to join $\mathrm{Cu}, \mathrm{Mg}$, Ti alloys, steel and aluminium, magnesium, steel based metal matrix composites [9, 10]. A prolific literature shows that FSW process can be successfully employed to weld difficulty-to-weld materials with improved mechanical

\footnotetext{
${ }^{*}$ Corresponding author: subramanya.prabhu@gmail.com
} 
properties, without weld defects [11]. But the presence of reinforced materials in the AMCs limits the range of welding parameters in comparison with the aluminium alloys.

Several review papers were available in the field of FSW process. Threadgill [9] reviewed the significance of FSW method used to join aluminium alloys. Mishra et al. [12] gave a meticulous review on friction stir welding and friction stir processing. Thomas et al. [13] and Zang et al. [14] discussed thoroughly about different FSW tools and their effect on FSW processes. Wang et al. [15] and Salih et al. [16] gave a detailed review on FSW of aluminium based metal matrix composites. Significance of FSW process variables on microstructure and mechanical properties of the welded joints are discussed in detail in their reviews. Fenoel et al. [17] systematically reviewed FSW of Metal matrix composites with various kinds of matrix material. They discussed modification occurs in the microstructure and mechanical properties of the friction stir welded zones in detail. The present paper reviews the latest development took place in FSW of AMCs. After a brief description of FSW method, comprehensive assessments of issues in the FSW of AMCs are addressed. Effects of FSW process on mechanical properties, micro and macrostructure of AMCs, welding defects and wear of tools are explained in the subsequent sections. The paper is ended with Conclusion and future research directions.

\section{FSW Process:}

FSW is a solid state, environment friendly welding process, where a non- consuming specially designed rotating tool is plunged into a pair of plates which are tightly held together on a back plate in a rigid FSW fixture (Fig. 1). The tool consists of shoulder and prolonged pin whose length is slightly less than the thickness of the welding plate. Rotating tool is inserted into the plates till the shoulder touches the top surface of the plate. The frictional heat is produced between the tool shoulder and the plate interface resulting in plasticization of the material below the shoulder. Rotating tool remains in the plunged position for a short duration of time. The tool made to traverse along the joint weld line after a short delay time. As the tool traverses, the plasticized material is get solidified behind the rotating tool. Plates are being welded due to both forging and extrusion effects. The tool is lifted at the end if the process, leaves a key hole of a size of rotating pin in the plates.

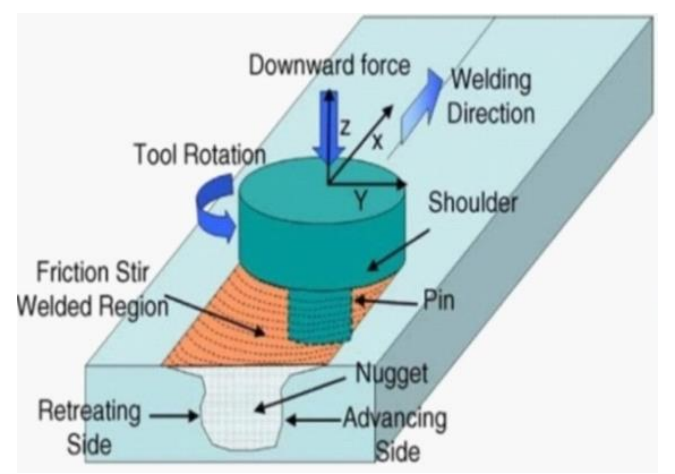

Fig. 1. Schematic illustration of FSW process [12].

The weld line divides the work piece into two parts, i.e. advancing side and retracting side [12]. The advancing side is a side where tool rotation and tool movement is in the same direction and in the retracting side the tool rotates opposite to that of tool movement. As the tool moves along the weld line, the plasticized softened material is swept from advancing side to the retracting side and gets solidified behind the rotating tool. The welding institute 
initially developed FSW process to join non weld-able aluminium alloy series, and then FSW technique is extended to join AMCs. Plates with dissimilar compositions or different metals can be joined by this technique. Composition compatibility can be ignored in FSW process which is a major concern in conventional fusion welding which leads to solidification cracking [18].

Various welding parameters affect the material flow around the tool pin which decides the quality and strength of the joint. Rotation speed of the tool, tool traverse speed, tool geometry, tool material, axial force and tool tilt angles are the major parameters influence the quality of the weld $[8,12]$.

\section{Grain Structure of a FSW Joint:}

Frictional heat generates at the rotating tool and work piece interface leads to rigorous plastic deformation of the material at the weld zone. The amount of heat induced due to the rotation of tool will be varied for different rotation speed of the tool. Defects are formed if the amount of heat induced in the weld zone either excessive or insufficient. The grain structure, mechanical strength and the quality of the joints depends upon the quantity of heat produced in the weld zone. Hence proper process parameters to be chosen to get good quality welds. By evaluating the macro and micro structure of the weld zone, the quality of the FSW can be assessed $[12,18,19]$.

\subsection{Macrostructure evaluation of Friction stir weld zone:}

Due to the variation in the thermo mechanical effect, four distinct zones are visible in the weld region. The grain size, orientation and distribution of particles are different at these four zones [12]. The zones are classified as Nugget zone (NZ) or stirred zone (SZ), Thermo mechanically affected zone (TMAZ), Heat affected zone (HAZ) and the parent or base material (PM or BM) as shown in the Fig. 2. The central zone of the weld area is called nugget or stirred zone which is substantially deformed by the rotating tool pin. Severe stirring action of the tool pin, heats up this area leads to the plastic deformation of the material. Fine equi-axed grains are visible in this area arranged in the form of onion shape [20] as depicted in Fig. 3. Softened material flow and dislocation density differences during the welding process are the main reason to form onion shaped structure in the NZ [21, 22].

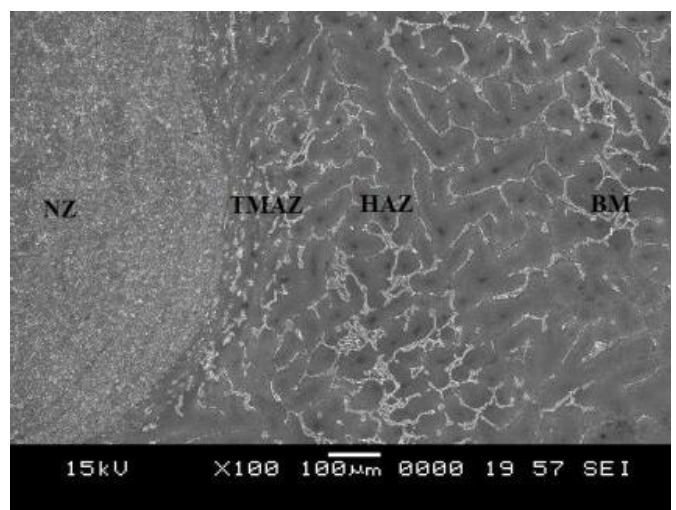

Fig. 2. Scanning Electron Micrograph showing various microstructural zones. [19]

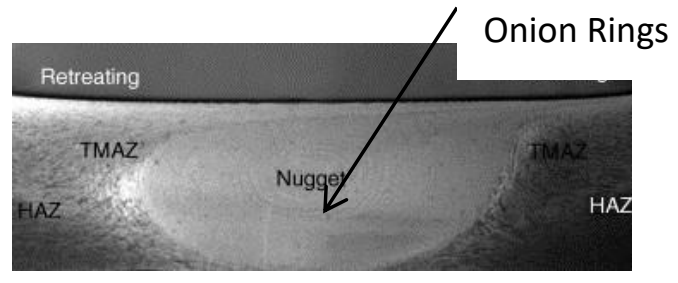

Fig. 3. Onion Ring structure in Nugget Zone [12] 
Next to nugget zone is TMAZ whose peak temperature is slightly lesser than that of NZ. The grains are elongated and oriented in the inclined direction due to the thermo mechanical effect of rotating tool. Heat affected zone which is in between Base material and TMAZ, experiences only heating effect. Rotating pin does not mechanically deform this area. Grains are coarsened due to the thermal effect. The peak temperature attains in HAZ is much less than that of TMAZ. The base material or parent material is unaffected zone where grain structure is not changed due to FSW.

Welding defects such as tunnel holes (Fig. 4) are visible during macrostructure assessment of the FS welded joint. Tunnel defect is formed mainly due to the inadequate heat input and inapposite flow of plasticized softened material in the weld zone. Nami et al. [27] pointed out that tunnel defects are formed at both low and high rotating speed. They showed that inappropriate material flow in the stirred zone due to either less heat input at low rotation speed of 700-900 rpm or excessive heat at the higher rotation speed of 1300 $1400 \mathrm{rpm}$, results in tunnel defects. Similarly Cioffi et al. [23] observed the formation of tunnel defects at low rotation speed and defect is disappeared as the rotation speed is increased to $800 \mathrm{rpm}$.

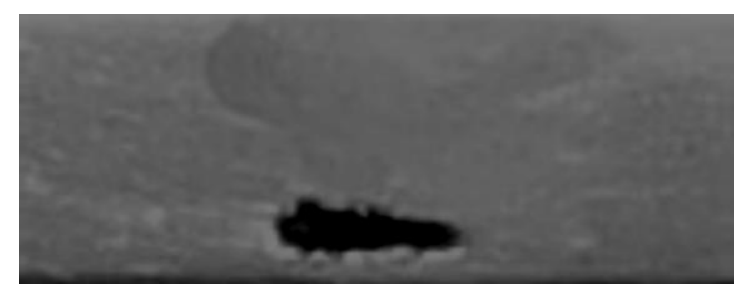

Fig. 4. Tunnel hole in cross section of an AA6061-4.5 Cu- 5 Sic joint welded at $1500 \mathrm{rpm}$ and $50 \mathrm{~mm} / \mathrm{min}[19]$

\subsection{Microstructure of FSW zone:}

During FSW process, the friction between the rotating tool and work piece increases the peak temperature in the weld zone up to 0.75 to 0.8 times of the melting temperature of the base material. Redistribution of reinforced particles, reorientation, grain refinement, recrystallization and grain growth will takes place due to the rise in the temperature at the stirred zone. During production of AMCs either by stir casting or powder metallurgy process, it is common that the reinforced particles are clustered, non-uniformly distributed in the matrix. This will affects the strength characteristics of the AMCs, which is different at different location, results in anisotropy mechanical properties. Stirring action and plastic deformation caused by the rotating pin, separates the clustered particles and redistributes the particles uniformly in the stirred zone [20, 23, 25-27]. Due to the stirring action, the edges of the reinforced particles are rounded off and the size of the particles decreases compared to the parent material. This occurs due to the abrasion and mixing effect between work piece and the circumference of rotating pin, shoulder face [5, 20, 28, 29]. Size of the particles is closer to the shoulder is smaller than the tool pin tip [30]. However there is no change in the particle size after FSW process, if the particle size is already smaller in the base material as reported by Storjohann et al. [28]. They show that particles were reoriented and bigger particles were exposed to grain refinement.

Periyasamy et al. [24] showed that lower heat input at the nugget zone results in faster cooling of plasticized material causes development of coarse grains due to the lack of complete recrystallization in this zone. On the contrary higher heat input at the nugget zone due to the high rotational speed, results in finer grain structure and eliminates dendritic structure in this zone. Fine equi axed grains are observed in stirred zone which is smaller 
than the base material grain size, indicates nucleation of new grains in this zone [32]. Wang et al. [33] observed high energy point on the broken surface of reinforced material (Sic) is the area of the nucleation and growth of the grains.

In conclusion, to attain superior mechanical properties in the AMCs, the reinforced materials are to be uniformly distributed in the matrix. Apposite FSW process parameters produces essential heat input results in proper material flow and uniform distribution of reinforced particles and improved joint quality. The sharp edges of reinforcements are rounded off and bigger particles are split into smaller one. FSW changes the design of the AMCs at the weld region by changing the spacing, distribution, morphology and size of the reinforced particles. This modification is caused by the dynamic recrystallization in the nugget zone. The reformed grain structure decides the properties of the AMCs at the weld zone.

\section{Mechanical properties of FS welded joints:}

Mechanical properties such as hardness and tensile strength of friction stir welded joints are depending on the process parameter. Optimization of process parameters, that yields the higher joint efficiency, is done by evaluating these properties.

\subsection{Micro hardness of joints:}

Micro hardness across the weld zone indicates the distribution of reinforced particles and various phases. In the weld zone two different micro hardness curve profiles are observed. One type of graph shows highest value of hardness in the stirred zone and its goes on decreasing along TMAZ and HAZ, and shows minimum value in the base material region as shown in Fig. 5 [24, 26, 27, 31, 33-35]. Refinement of grain caused by dynamic recrystallization and proper distribution of particles due to the severe stirring action of FSW tool, results in higher hardness at the stirred zone. Decrease in heat input at the nugget zone leads to the incomplete recrystallization, develops coarser grain and there by reduces the hardness (Fig. 5).

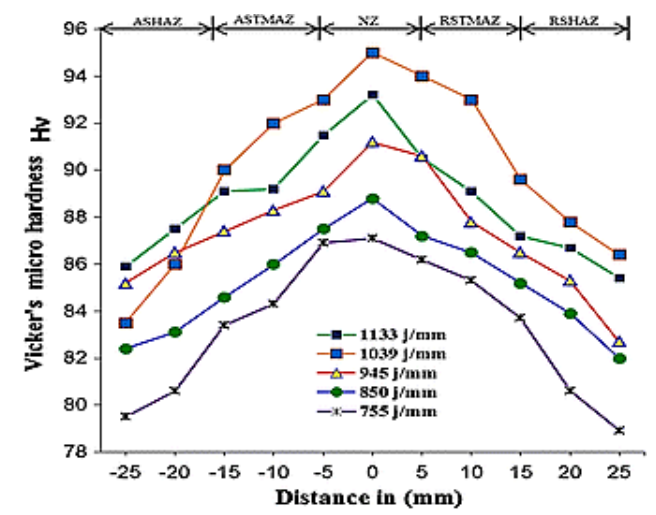

Fig. 5. Effect of heat input of welding process on micro hardness profile across the weld region of AA6061-10 SiC [24]

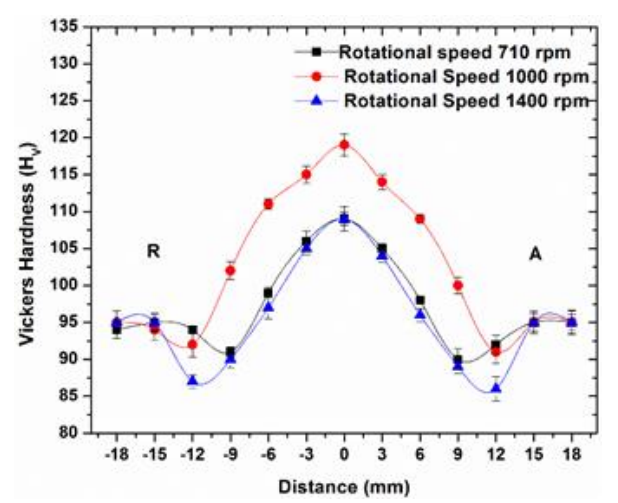

Fig 6. Micro hardness profile distribution across the weld zone of AA6061-4.5Cu-10SiC [19]

Second type of graph shows the lowest hardness at the HAZ, and highest value in the $\mathrm{NZ}$ as shown in the Fig. $6[20,23,25,36]$. In the microstructural analysis it was observed that the microstructure of TMAZ show the transition of base metal into nugget zone. TMAZ is characterized by the elongated grains, where the material is plastically deformed 
and thermally affected. Temperature attained in HAZ is sufficient to cause dissolution of fine secondary precipitate. The dissolution of fine strengthening precipitate in turn promotes coarsening of aluminium grains which led to reduction in hardness value at HAZ. Hence $\mathrm{W}$ shaped hardness distribution across the joint profile is observed.

\subsection{Tensile Properties of FS Welded Joints:}

Compared with conventional fusion welding, FSW yields higher joint efficiency. Joint efficiency is defined as the ratio of tensile strength of friction stir welded AMC to that of Base material. Various factors affect the joint efficiency such as process variables, tool profile and development of intermetallic compounds. Table 1 summarizes the joint efficiencies of AMCs welded by FSW.

\subsubsection{Effect of Process parameters:}

FSW process parameters such as rotation speed of the tool, tool traverse speed and axial force affects the quantity of heat generated at the tool - work piece interface, stirring of softened material and finally solidification of the material behind the rotating tool and forming the joint. To obtain superior quality joints, it is necessary to choose optimum process parameters. The joint efficiency is normally in the range of 60 to $96 \%$ of those of the base material. UTS of welded joints can be increased by increasing the rotational speed up to a certain limit. Several researchers [20, 24, 26, 27, 37] are reported that maximum UTS is attained by using a rotational speed in the range of 1000 to $1200 \mathrm{rpm}$ depending on the type of AMCs. Rotational speed less than $1000 \mathrm{rpm}$ results in inadequate heat input, affect the plasticization and proper mixing of material in the weld zone. Similarly rotational speed higher than $1200 \mathrm{rpm}$ results in excessive heat input, leads to turbulent material flow in the nugget zone, thereby deteriorates the weld quality and strength.

Tool traverse speed is another important factor which affects the strength of the joint. The amount of heat transfers to the work piece, which is generated at the tool work piece interface and the rate at which material cools and solidifies, is depended on the tool traverse speed.

Several researchers [36, 37-39] are pointed out that there is no proportional relation between tool traverse speed and the UTS of the joint. Increase in tool traverse speed increases the UTS of the joint up to a certain value then it start decreasing as the traverse speed further increases. The quantity of heat induced at the weld zone depends on the tool rotation speed. Whereas the amount of heat transferred to the work piece and rate at which work piece cools behind the moving tool is influenced by the tool traverse speed [19]. For the given rotational speed of the tool, lower tool traverse speed increases the amount of heat transferred to the work piece and reduces the cooling rate, results in formation of coarser grains. Higher tool traverse speed results in lesser heat transferred to the work piece and increases cooling rate. This leads to softened material in the welding zone experiences improper stirring action results in low quality welds. Both high and low tool traverse speed results in tunnel defect. Therefore lesser UTS is observed at both low and high tool traverse speed. Wang et al. [36] showed that joint efficiency increases as the traverse speed increases and attains maximum value of $97 \%$ at $800 \mathrm{~mm} / \mathrm{min}$. At lower traverse speed, the work piece fails at HAZ (a low hardness zone) due to the dissolution and growth of precipitates. This will reduces strength of the joint. On the contrary, higher traverse speed increases the cooling rate results in partially dissolving clusters in the matrix. This results in increase in the hardness of HAZ and failure of joint is shifted from HAZ to NZ. Thus joint efficiency is increases as the traverse speed increases. 
Table 1. FSW process variables and joint efficiency of AMC joints.

\begin{tabular}{|c|c|c|c|c|c|c|c|}
\hline Base Material & Tool Material & Tool Geometry & $\begin{array}{l}\text { Rotation } \\
\text { Speed } \\
\text { RPM }\end{array}$ & $\begin{array}{l}\text { Traverse } \\
\text { Speed } \\
\mathrm{mm} / \mathrm{min}\end{array}$ & $\begin{array}{l}\text { Axial } \\
\text { force } \\
(\mathrm{kN})\end{array}$ & $\begin{array}{l}\text { Joint } \\
\text { Efficie } \\
\text { ncy }\end{array}$ & $\begin{array}{l}\mathrm{Re} \\
\mathrm{f} .\end{array}$ \\
\hline $\begin{array}{l}\text { AA6061/4.5Cu } \\
/ 5 \mathrm{SiC}\end{array}$ & $\begin{array}{l}\text { Tool Steel (60 } \\
\text { HRC) }\end{array}$ & $\begin{array}{l}\text { Combined Square } \\
\text { and Threaded } \\
15-6-5.7\end{array}$ & $710-1400$ & $50-80$ & - & $90 \%$ & 19 \\
\hline $\begin{array}{l}\text { AA } 2124 / \\
25 \mathrm{SiC}\end{array}$ & - & Cylinder thread & 1120 & 40 & - & 81 & 20 \\
\hline $\begin{array}{l}6061 / 20 \mathrm{Al}_{2} \mathrm{O}_{3} \\
7005 / 10 \mathrm{Al}_{2} \mathrm{O}_{3}\end{array}$ & - & - & 800 & 56 & - & 83.87 & 21 \\
\hline $\begin{array}{l}\mathrm{AA} 2124 / \\
25 \mathrm{SiC}\end{array}$ & $\begin{array}{l}\text { H13 Steel } \\
48 \text { HRC }\end{array}$ & $\begin{array}{l}\text { Cylinder thread } \\
20-7.95 \text { to } 6.35- \\
7.62\end{array}$ & 550 & 75 & 8.5 & 86.5 & 23 \\
\hline $\begin{array}{l}\text { AA } 6061 / 10 \\
\mathrm{SiC}\end{array}$ & $\begin{array}{l}\text { High Speed } \\
\text { steel }\end{array}$ & $\begin{array}{l}\text { Cylinder thread } \\
18-6-5.7\end{array}$ & 1100 & 45 & 6 & 74 & 24 \\
\hline $\begin{array}{l}\mathrm{AA} 2009 / 17 \\
\mathrm{SiC}\end{array}$ & Cermet & $\begin{array}{l}\text { Cylindrical with } \\
\text { Triangular tip } \\
14-5-2.7\end{array}$ & 1000 & 50 & - & 77 & 25 \\
\hline $\begin{array}{l}\text { AA6061/12 } \\
\mathrm{B}_{4} \mathrm{C}\end{array}$ & $\begin{array}{l}\text { High carbon } \\
\text { high chromium } \\
\text { steel ( } 62 \text { HRC) }\end{array}$ & $\begin{array}{l}\text { Square } \\
18-6-5.7\end{array}$ & 997 & 78 & 9.3 & 96.83 & 26 \\
\hline $\mathrm{Al} / \mathrm{Mg}_{2} \mathrm{Si}$ & H13 Steel & $\begin{array}{l}\text { Tapered }\left(7^{\circ}\right) \\
\text { Cylindrical } \\
\text { Threaded } \\
18-6-5.7\end{array}$ & $710-1400$ & 125 & - & $\sim 100$ & 27 \\
\hline $\begin{array}{l}\mathrm{AA} 6061 / \\
20 \mathrm{Al}_{2} \mathrm{O}_{3}\end{array}$ & $\begin{array}{l}\text { Ultra-hard } \\
\text { material }\end{array}$ & $\begin{array}{l}\text { Cylindrical } \\
20-8-?\end{array}$ & 700 & 300 & - & 70 & 28 \\
\hline $\begin{array}{l}\mathrm{AA} 6061 / \\
22 \mathrm{Al}_{2} \mathrm{O}_{3}\end{array}$ & $\begin{array}{l}\text { Wear resistant } \\
\text { steel } 64 \text { HRC }\end{array}$ & $\begin{array}{l}\text { Cylindrical } \\
15-4-?\end{array}$ & 880 & 260 & - & 99 & 29 \\
\hline $\mathrm{Al} / 4.5 \mathrm{Cu} / \mathrm{TiB}_{2}$ & $\begin{array}{l}\text { M2 Steel(62 } \\
\text { HRC) }\end{array}$ & $\begin{array}{l}\text { Cylindrical } \\
\text { Threaded 18-6-5 }\end{array}$ & $710-1400$ & 63 & - & - & 30 \\
\hline $\begin{array}{l}\text { AA 2009/ } \\
15 \mathrm{SiC}\end{array}$ & Steel & $\begin{array}{l}\text { Cylindrical } \\
\text { Threaded 24-8-? }\end{array}$ & 600 & 5 & - & 95 & 31 \\
\hline $\begin{array}{l}\text { AA 2009/ } \\
15 \mathrm{SiC}\end{array}$ & $\begin{array}{l}\text { Ultra hard } \\
\text { Cermet }\end{array}$ & Conical 20-8-5.8 & 800 & 100 & & 82 & 32 \\
\hline $\mathrm{LM} 25 / 5 \mathrm{SiC}$ & $\begin{array}{l}\text { HSS Coated } \\
\text { with TiAlN }\end{array}$ & $\begin{array}{l}\text { 19.5-6/4-5.7 } \\
\text { Tapered }\end{array}$ & $\begin{array}{l}1200- \\
1800\end{array}$ & $20-60$ & $6 / 7 / 8$ & & 33 \\
\hline $\mathrm{AA} 6061 / \mathrm{ZrB}_{2}$ & $\begin{array}{l}\text { High carbon } \\
\text { high chromium } \\
\text { steel ( } 62 \text { HRC) }\end{array}$ & $\begin{array}{l}\text { Square } \\
18-6-5.7\end{array}$ & 1150 & 50 & 6 & 94-95 & 34 \\
\hline $\begin{array}{l}\mathrm{Al} / 4.5 \mathrm{Cu} / \\
10 \mathrm{TiC}\end{array}$ & $\begin{array}{l}\text { Steel Shoulder } \\
\text { Titanium pin }\end{array}$ & Threaded $18-7-4.8$ & 500 & 20 & 6 & 89 & 35 \\
\hline $\begin{array}{l}\text { AA6061-T6/ } \\
\text { AlNp }\end{array}$ & $\begin{array}{l}\text { High carbon } \\
\text { high chromium } \\
\text { steel ( } 62 \text { HRC) }\end{array}$ & $\begin{array}{l}\text { Square } \\
18-6-5.7\end{array}$ & $\begin{array}{l}1000- \\
1400\end{array}$ & $25-85$ & $3-7$ & 93.42 & 37 \\
\hline $\begin{array}{l}\mathrm{AA} 6061 / 4.5 \mathrm{Cu} \\
/ 10 \mathrm{SiC}\end{array}$ & $\begin{array}{l}\text { Tool Steel ( } 60 \\
\text { HRC) }\end{array}$ & $\begin{array}{l}\text { Combined Square } \\
\text { and Threaded } \\
15-6-5.7\end{array}$ & $710-1400$ & $50-80$ & - & $90 \%$ & 38 \\
\hline AA6061/AlNp & $\begin{array}{l}\text { High carbon } \\
\text { high chromium } \\
\text { steel }(62 \text { HRC) }\end{array}$ & $\begin{array}{l}\text { Square } \\
18-6-5.7\end{array}$ & 1200 & 55 & 5 & 93.42 & 39 \\
\hline $\mathrm{Al} / 12 \mathrm{Si} / 10 \mathrm{TiC}$ & $\begin{array}{l}\text { Steel Shoulder } \\
\text { Titanium pin }\end{array}$ & $\begin{array}{l}\text { Threaded } \\
18 / 20 / 22-7-5.8\end{array}$ & $710-100$ & $20-40$ & - & - & 40 \\
\hline $\mathrm{AA} 6061 / 12 \mathrm{~B}_{4} \mathrm{C}$ & $\begin{array}{l}\text { high carbon } \\
\text { high chromium } \\
\text { steel ( } 62 \text { HRC) }\end{array}$ & $\begin{array}{l}\text { Square } \\
18-6-5.7\end{array}$ & 997 & 78 & 9.3 & 96.83 & 41 \\
\hline $\mathrm{Al} / 10 \mathrm{TiB}_{2}$ & $\begin{array}{l}\text { High carbon } \\
\text { high chromium } \\
\text { steel }\end{array}$ & $\begin{array}{l}\text { Various tool pin } \\
\text { profile }\end{array}$ & 2000 & 30 & 19.6 & 99.47 & 42 \\
\hline
\end{tabular}

Tool geometry information includes shoulder dia- pin dia (x/y with $\mathrm{x}$ at root and $\mathrm{y}$ at tip if conical or pin side if square- pin length. All dimensions are in $\mathrm{mm}$. 
Few studies $[20,35,40]$ showed that the effect of traverse speed on the joint efficiency is not much significant as that of other process variables such as rotation speed, axial force and tool geometry. They found marginally inverse relation of traverse speed with UTS of joint. As the traverse speed increases, the UTS of joint decreased. Traverse speed of 20 $\mathrm{mm} / \mathrm{min}$ and $40 \mathrm{~mm} / \mathrm{min}$ are the best suited for FSW of SiC reinforced and TiC reinforced composite respectively.

Another significant parameter in FSW is applied axial force. The friction coefficient quantified by the applied axial force, governs the quantity of heat induced due to the friction between tool and the work piece. Higher axial force results in increased heat input at the weld zone, results in proper material flow. Defect less, high quality and better joint strength can be attained with appropriate axial force.

Several researchers analyzed the effect of axial force on the FS welded joint strength. Lower axial force, less than $5 \mathrm{kN}$, results in lesser heat generation leads to the tunnel defect in FSW of AA6060/AlNp [37]. On the contrary axial force more than $5 \mathrm{kN}$ causes thinning of stirred zone and worm hole formation. Thus axial force beyond the optimum value results in drop in joint efficiency.

Similar results were shown by Dinaharan and Murugan [38]. Joint strength of FS welded AA6061/ZrB2, shows higher value for the axial force of $6 \mathrm{kN}$. Excessive flash and thinning of nugget zone is observed for forces larger than 6 and formation of micro voids are visible for the axial force less than $6 \mathrm{kN}$. Kalaiselvan and Murugan [41] were pointed out similar finding in their work of $\mathrm{FSW}$ of $\mathrm{B}_{4} \mathrm{C}$ reinforced AA6061 matrix with an ideal force of $10 \mathrm{KN}$.

In conclusion, UTS of FSW joint greatly affected by the Process variables including tool traverse speed, rotational speed and axil force. In comparison with other two factors, rotational speed has the major effect on UTS of the joint. However there is no fixed relation between process parameter and the joint strength, for all types of AMCs. Therefore each AMCs needs its own analysis to accomplish its maximum joint strength.

\subsubsection{Effect of tool Profile:}

Different shoulder profiles (concave, convex, flat) and pin geometries (Cylindrical, Square, triangular, hexagonal, straight tapered etc.) are used by researchers to carry out FSW.

Kumar et al. [35] studied the effect of shoulder surface ( $2 \mathrm{~mm}$ flat, $1 \mathrm{~mm}$ flat and fully flat surface) with $7^{\circ}$ concave angle on the tensile properties and suggested shoulder with $2 \mathrm{~mm}$ flat surface gives higher tensile strength. Higher contact surface between tool and work piece induces higher heat, results in proper mixing of softened material in the nugget zone. Yigezu et al. [40) studied the effect of shoulder diameter on tensile properties with three different diameters $(18,20$ and $22 \mathrm{~mm})$. They reported that to obtain maximum efficiency, shoulder with $20 \mathrm{~mm}$ diameter is preferred.

Vijay and Murugan [42] showed that straight square profiled pin delivers highest tensile strength with a joint efficiency $99.47 \%$ in comparison with all other tool profiles like cylindrical hexagonal and orthogonal, both tapered and straight. Higher volume ratio (ratio of swept volume during rotation to the static volume) of the tool results in higher joint efficiency. Volume ratio of square, hexagon and octagon pin geometries are 1.56, 1.21 and1.11 respectively Wang et al. [36] and Hassan et al. [43] showed that conical threaded pin at high welding speed, gives higher joint efficiency compared to straight cylinder pin. This is due to the enhancement in the flow ability of softened material. 


\subsubsection{Effect of heat treatment and strain rate:}

Post weld heat treatment, development of intermetallic compounds and strain rate also influences the joint strength. Feng et al. [31] explored the effect of post weld treatment on FS welded AA2009/SiC/15p composite. Heat treatment enhanced the joint efficiency both in longitudinal and traverse direction and reached $82 \%$ and $95 \%$ respectively. They reported that in the stirred zone the development of secondary phase caused by interaction of base material and the tool worn out material reduces the joint efficiency. Formation of the secondary phases can be eliminated by using ultra hard tool material. Wang et al. [36] achieved nearly $100 \%$ joint efficiency after T4-treatment. Ni et al. [44] investigated the strain rate effect on strain hardening and mechanical properties of SiC reinforced AA2009 composite. Minor reduction in the tensile strength is observed as the strain rate increased and most of the specimens are fractured in the HAZ of retreating Side.

\section{Tool wear in FSW of AMCs:}

FSW tools made of standard materials have a negligible wear rate when used to weld softer materials like aluminium and its alloys. But they experience higher wear in the welding of harder materials like aluminium matrix composites and steels. Presence of hard reinforcing materials resulting in abrasion of tool material leads to the tool wear as shown in Fig. 7. If the hardness of tool material is more than the work piece, nearly no tool wear is observed. However the lower hardness of tool compare to the work piece leads to the higher tool wear. [45]. Reduction of the pin length or, erosion of tool profile due to the tool wear hampers the material flow, which increases the welding defect [46]. Root flaw defect is formed due to the lack of consolidated material at the base of the joint due to the reduction in the pin length. The tool wear mechanism is depends upon tool geometry interaction between the tool and work material and welding parameters. The wear in polycrystalline cubic boron nitride (PCBN) tools is mainly due to adhesive wear at low rotation speed while its due to abrasive wear at high tool rotational speed [12, 47]. Liu et al. [48] observed that diminution in the diameter of the pin with increasing weld length. Severe wear is noticed in the radial direction whereas negligible changes are seen in the shoulder size and pin length. Radial wear of the pin mainly depends upon the welding speed. Higher wear rate is observed during low welding speed and its maximum in the initial welding. Prater [45] reported the volumetric wear of the tool to the process parameters, i.e., rotation speed $(\omega)$, traverse speed $(v)$ and distance welded (l). He has shown existence of direct proportionality between wear and linear weld length in his studies.

Fernandez and Murr [49] explained that as the tool rotation speed increases, tool wear also increases, whereas tool wear decreases as the welding speed increases. They experimentally proved that, In the FSW process, tool wear was shear phenomenon than drag phenomenon. Prado et al. [50] examined the tool wear rate in FSW of Al6061 + Al2O3 composite and showed that severe wear is observed during FSW of composite whereas no apparent wear for FSW of A16061. They showed that the tool wear is increases as the tool rotation speed increases and it reaches maximum for the speed of 1000rpm and then it decreases as the speed increases beyond $1000 \mathrm{rpm}$ due to the increases fluid like behavior and turbulent material flow. They also noticed that enough tool material is removed at the beginning of the welding. However as the welding continues the wear rate decreases and tool attain a self-optimized shape, where no more tool wear is observed. Tool will lose its initial shape due to the tool wear but still produces good quality weld after attaining self-optimized shape. 

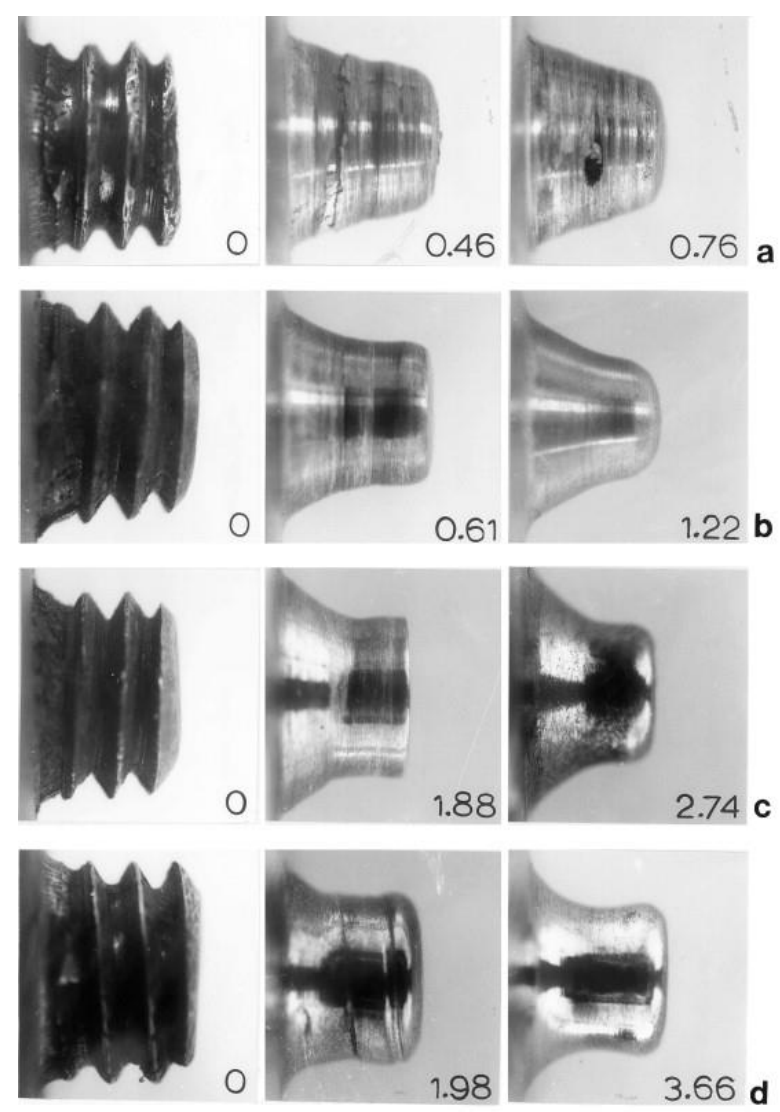

Fig. 7. Tool pin sequences showing wear features for constant rotation speed of $1000 \mathrm{rpm}$ for specific traverse speeds. (a) $T=60 \mathrm{~mm} / \mathrm{min}$; (b) $T=180 \mathrm{~mm} / \mathrm{min}$; (c) $T=360 \mathrm{~mm} / \mathrm{min}$; (d) $T=540 \mathrm{mmimin}$. Traverse distance showed in meters [50].

\section{Summary}

Various aspects of FSW process is reviewed including process parameters, their effect on mechanical properties, modifications in the microstructure of weld zone and tool wear. As a solid state joining technique, FSW eliminates the defects of conventional fusion welding in AMCs such as non-uniform distribution of reinforcements, formation of deleterious phases, porosity etc. Superior joints with better mechanical properties could be attained by FSW. However research in FSW is still in its early stage and potential application of this technique to join AMCs in industry is yet to be implemented.

The joint strength and weld quality of AMCs joint are mainly dependent on composition of AMCs and the process parameters. Hence the performance of the AMCs joined by FSW should be assessed by considering both composition and process variables. Lot of research is going on to study the effect of process parameters on the joint strength. However meager studies are done to understand the effect of type and percentage of reinforcement on joint efficiency. Future studies should emphasize on the preparation of those composite with required percentage of reinforcement which gives better mechanical properties.

Selection of apposite process variables plays a key role in obtaining high quality joint with better properties. To have better material flow, material mixing and thereby to get sound joint, a large amount of heat to be induced during FSW. High heat input can be 
achieved by increasing the tool rotational speed and reducing the tool traverse speed. However this leads to tool wear. Generally a tradeoff between tool wear and higher heat input is found in FSW. Range of process variables used in FSW of AMCs is narrower compared to the aluminium and its alloys. Also each AMCs acts differently for given value of process parameters. Future study should focus on creating a FSW window for each AMCs for optimized mechanical performance. Also there is need for analyzing the fracture toughness and fatigue strength of FS welded AMCs to explore the potential application FSW of AMCs in industries.

Key issue in FSW of composites, reinforced with hard materials is severe wear of tool, and it is major limiting factor for the large scale industrial application of FSW. Tools with surface coating, tool made of wear resistant material, heat treatment of tools are some of the doable solution to overcome the tool wear.

\section{References:}

1. N. Chawla, K.K. Chawla, Metal Matrix Composites, (Springer, 2006).

2. M. Haghshenas, Metal-Matrix Composites, In Reference Module in Materials Science and Materials Engineering, (Elsevier, 2016).

3. M.B.D. Ellis, Joining of aluminium based metal matrix composites, Int. Mater. Rev., 41(2), 41-58, (1996).

4. Pal, T.K., Joining of aluminium metal matrix composites, Mater. Manuf. Process., 20, 717-726, (2005).

5. D. Storjohann, O.M. Barabash, S.S. Babu, S.A. David, P.S. Sklad, E.E. Bloom, Fusion and friction stir welding of aluminum metal-matrix composites, Metall. Mater. Trans. A, 36A, 3237-3247, (2005).

6. K. Peng, H.C. Cui, F.G. Lu, X. M. Wu, X.H. Tang, S. Yao, S.N. Lou, Mechanical properties and wear resistance of aluminum composites welded by electron beam, Trans. Nonferrous Metals Soc. China, 21, 1925-1931, (2011).

7. J. Niu, L. Pan, M.Wang, C. Fu, X. Meng, Research on laser welding of aluminium matrix composite $\mathrm{SiCw} / 6061$, Vacuum, 80, 1396-1399, (2006).

8. W. Thomas, E. Nicholas, J. Needham, M. Murch, P. Temple-Smith, and C. Dawes, Friction Stir Butt Welding, International Patent No. PCT/GB92/02203, GB Patent No. 9125978.8, 1991, U.S. Patent No. 5,460,317, 1995. (1991).

9. P.L. Threadgill, A.J. Leonard, H.R. Shercliff, P.J. Withers, Friction stir welding of aluminium alloys, Int. Mater. Rev., 54(2), 49-93, (2009).

10. G. Cam, Friction stir welded structural materials: beyond Al-alloys, Int. Mater. Rev., 56(1), 1-47, (2011).

11. R. Nandan, T. DebRoy, H.K.D.H. Bhadeshia, Recent advances in friction stir welding process, weldment structure and properties, Prog. Mater. Sci., 53, 980-1023, (2008).

12. R.S. Mishra, Z.Y. Ma, Friction stir welding and processing, Mater Sci Eng R, 50, 1-78, (2005).

13. W.M. Thomas, D.G. Staines, I.M. Norris, R. de Frias, Friction stir welding tools and developments, Weld. World, 47, 10-17, (2013).

14. Y.N. Zhang, X. Cao, S. Larose, P.Wanjara, Review of tools for friction stir welding and processing, Can. Metall. Q., 51(3), 250-261, (2012).

15. D. Wang, B.L. Xiao, D.R. Ni, Z.Y. Ma, Friction stir welding of discontinuously reinforced aluminum matrix composites: a review, Acta Metall Sin, 27, 816-824, (2014).

16. O.S. Salih, H. Ou,W. Sun,M.C. DG, A review of friction stir welding of aluminium matrix composites, Mater. Des., 86, 61-71,(2015). 
17. M. A. Fènoël, A. Simar, A review about Friction Stir Welding of metal matrix composites, Materials Characterization, 120, 1-17, (2016).

18. R.S. Mishra, P.S. De, N. Kumar, Friction Stir Welding and Processing, Science and Engineering, (Springer, London, 2014).

19. S. Prabhu, A. K. Shettigar. K. Rao, S. Rao and M. Herbert, Influence of Welding Process Parameters on Microstructure and Mechanical Properties of Friction Stir Welded Aluminium Matrix Composite, Materials Science Forum, 880, 50-53, (2017).

20. Y. Bozkurt, H. Uzun, S. Salman, Microstructure and mechanical properties of friction stir welded particulate reinforced AA2124/SiC/25p-T4 composite, J. Compos. Mater., 45(21), 2237-2245, (2011).

21. P. Cavaliere, E. Cerri, L. Marzoli, J. Dos Santos, Friction stir welding of ceramic particle reinforced aluminium based metal matrix composites, Appl. Compos. Mater., 11, 247-258, (2004).

22. L. Ceschini, I. Boromei, G. Minak, A. Morri, F. Tarterini, Microstructure, tensile and fatigue properties of AA6061/20 vol. $\% \mathrm{Al}_{2} \mathrm{O}_{3} \mathrm{p}$ friction stir welded joints, Compos. A: Appl. Sci. Manuf., vol. 38, no.4, pp. 1200-1210, 2007.

23. F. Cioffi, R. Fernández, D. Gesto, P. Rey, D. Verdera, G. González-Doncel, Friction stir welding of thick plates of aluminum alloy matrix composite with a high volume fraction of ceramic reinforcement, Compos. A: Appl. Sci.Manuf, 54, 117-123, (2013).

24. P. Periyasamy, B. Mohan, V. Balasubramanian, Effect of heat input on mechanical and metallurgical properties of friction stir welded AA6061-10\% SiCp MMCs, J. Mater. Eng. Perform, 21(11), 2417-2428, (2012).

25. D.R. Ni, D.L. Chen, D.Wang, B.L. Xiao, Z.Y. Ma, Influence of microstructural evolution on tensile properties of friction stir welded joint of rolled SiCp/AA2009T351 sheet, Mater. Des., 51,199-205, (2013).

26. K. Kalaiselvan, I. Dinaharan, N. Murugan, Characterization of friction stir welded boron carbide particulate reinforced AA6061 aluminum alloy stir cast composite, Mater. Des., 55, 176-182, (2014).

27. H. Nami, H. Adgi, M. Sharifitabar, H. Shamabadi, Microstructure and mechanical properties of friction stir welded $\mathrm{Al} / \mathrm{Mg} 2 \mathrm{Si}$ metal matrix cast composite, Mater. Des., 32(2), 976-983, (2011).

28. L.M. Marzoli, A.V. Strombeck, J.F. Dos Santos, C. Gambaro, L.M. Volpone, Friction stir welding of an AA6061/ $\mathrm{Al}_{2} \mathrm{O}_{3} / 20$ p reinforced alloy, Compos. Sci. Technol., 66(2), 363-371, (2006).

29. G. Minak, L. Ceschini, I. Boromei, M. Ponte, Fatigue properties of friction stir welded particulate reinforced aluminium matrix composites, Int. J. Fatigue, 32(1), 218-226, (2010).

30. S. Peddavarapu, S. Raghuraman, R. J. Bharathi, G. V. Sunil and Manikanta, Micro Structural Investigation On Friction Stir Welded Al--4.5Cu--5TiB 2 Composite, Transactions of the Indian Institute of Metals, 70(3), 703-708, (2017).

31. Feng, B. Xiao, Z. Ma, Effect of microstructural evolution on mechanical properties of friction stir welded AA2009/SiCp composite, Compos. Sci. Technol., 68(9), 21412148, (2008).

32. D. Wang, B.L. Xiao, Q.Z.Wang, Z.Y. Ma, Evolution of the microstructure and strength in the nugget zone of friction stir welded $\mathrm{SiCp} / \mathrm{Al}-\mathrm{Cu}-\mathrm{Mg}$ composite:, J. Mater. Sci. Technol., 30(1), 54-60, (2014).

33. C. Devanathan, A.S. Babu, Friction stir welding of metal matrix composite using coated tool, Proc Mater Sci, 6, 1470-1475, (2014).

34. Dinaharan, N. Murugan, Effect of friction stir welding on microstructure, mechanical and wear properties of AA6061/ZrB 2 in situ cast composites, Mater. Sci. Eng. A, 543, 257-266, (2012). 
35. A. Kumar, M.M. Mahapatra, P.K. Jha, N.R. Mandal, V. Devuri, Influence of tool geometries and process variables on friction stir butt welding of $\mathrm{Al}-4.5 \% \mathrm{Cu} / \mathrm{TiC}$ in situ metal matrix composites, Mater. Des., 59, 406-414, (2014).

36. D. Wang, Q.Z. Wang, B.L. Xiao, Z.Y. Ma, Achieving friction stir welded SiCp/Al$\mathrm{Cu}-\mathrm{Mg}$ composite joint of nearly equal strength to base material at high welding speed, Mater. Sci. Eng. A, 589, 271-274, (2014).

37. N. Murugan, B. Ashok Kumar, Prediction of tensile strength of friction stir welded stir cast AA6061-T6/AlNp composite, Mater. Des., 51, 998-1007, (2013).

38. A. K. Shettigar, S. Prabhu, R. Malghan, S. Rao and M. Herbert, Application of Neural Network for the Prediction of Tensile Properties of Friction Stir Welded Composites, Materials Science Forum, 880, 128-131, (2017).

39. B. Ashok Kumar, N. Murugan, Optimization of friction stir welding process parameters to maximize tensile strength of stir cast AA6061-T6/AlNp composite, Mater. Des., 57, 383-393, (2014).

40. B.S. Yigezu, D. Venkateswarlu, M.M.Mahapatra, P.K. Jha, N.R.Mandal, On friction stir butt welding of $\mathrm{Al}+12 \mathrm{Si} / 10 \mathrm{wt} \% \mathrm{TiC}$ in situ composite, Mater. Des., 54, 10191027, (2014).

41. K. Kalaiselvan, N. Murugan, Role of friction stir welding parameters on tensile strength of AA6061- $\mathrm{B}_{4} \mathrm{C}$ composite joints, Trans. Nonferrous Metals Soc. China, 23(3), 616-624, (2013).

42. S.J. Vijay, N.Murugan, Influence of tool pin profile on the metallurgical and mechanical properties of friction stir welded $\mathrm{Al}-10 \mathrm{wt} . \% \mathrm{TiB}_{2}$ metal matrix composite, Mater. Des., 31(7), 3585-3589, (2010).

43. A.M. Hassan, T. Qasim, A. Ghaithan, Effect of pin profile on friction stir welded aluminum matrix composites, Mater. Manuf. Process, 27(12), 1397-1401, (2012).

44. D.R. Ni, D.L. Chen, D. Wang, B.L. Xiao, Z.Y. Ma, Tensile properties and strain hardening behavior of friction stir welded SiCp/AA2009 composite joints, Mater. Sci. Eng. A, 608, 1-10, (2014).

45. T.Prater, M. S. Alvin, E. C. George, T. G. Brian, D. C. Chase, A comparative evaluation of the wear resistance of various tool materials in friction stir welding of metal matrix composites, Journal of Materials Engineering and Performance, 22, 1807-1813, (2013).

46. A. Bist, S. J. Saini, B. Sharma, A review of tool wear prediction during friction stir welding of aluminium matrix composite, Trans Nonferrous Met Soc China, 26, 20032018, (2016).

47. M. Collier, R. Steel, T. Nelson, C. Sorensen and S. Packer, Grade development of polycrystalline cubic boron nitride for friction stir processing of ferrous alloys, Materials Science Forum, 426-432, 3011-3016, (2003).

48. F. J. Liu, J. C. Feng, H. Fujii and K. Nogi, Wear characteristics of a WC-Co tool in friction stir welding of $\mathrm{AC} 4 \mathrm{~A}+30 \%$ vol. SiCp composite, International Journal of Machine Tools and Manufacture, 45, 1635-1639, (2005).

49. G. J. Fernandez, L. E. Murr, Characterization of tool wear and weld optimization in the friction-stir welding of cast aluminum $359+20 \% \mathrm{SiC}$ metal matrix composite, Materials Characterization, 52, 65-75, (2004).

50. R. A. Prado, L. E. Murr, K. F. Soto, J. C. Mcclure, Self-optimization in tool wear for friction-stir welding of $\mathrm{Al} 6061+20 \% \mathrm{Al}_{2} \mathrm{O}_{3}$, Materials Science and Engineering A, 349, 156-165, (2003). 